DOI 10.1515/ethemes-2015-0012

\section{SOCIAL CHALLENGES ARE OPPORTUNITIES FOR SUSTAINABLE DEVELOPMENT: TRACING IMPACTS OF SOCIAL ENTREPRENEURSHIP THROUGH INNOVATIONS AND VALUE CREATION}

\section{Iva Konda}

School of Business and Management Novo mesto, Slovenia

\iva.konda@guest.arnes.si

\section{Jasmina Starc}

Faculty of Business and Management Sciences Novo mesto, Slovenia $\bowtie$ jasmina.starc@guest.arnes.si

\section{Barbara Rodica}

School of Business and Management Novo mesto, Slovenia $\bowtie$ barbara.rodica@guest.arnes.si

UDC

005.961:

005.914.3:

316.3

Review paper

Received:

12.01 .2015

Accepted:

26.06.2015

\begin{abstract}
Today the world faces many social challenges in the economic, social and environmental spheres that needs to be overcome. The public debate has been focused on finding solutions to them and one of these has been addressed as social entrepreneurship. This phenomenon combines the resourcefulness of traditional entrepreneurship with a mission to change society. Observing the positive social impact of entrepreneurs providing basic needs, this paper recognizes their unique role in efficiently contributing to the achievement of sustainable development goals. The purpose of this article is to introduce the connection of social innovations and sustainable growth as an important phenomenon in today's real economy. Based on the interviews with the focus group and the cases of good practice, the authors have established the development of social innovation and social entrepreneurship in Slovenia. It is important in numerous fields, especially in employment, social inclusion, demographic changes, health care, education, finance, political structures and social integration. We found that the obstacle in the development of social entrepreneurship is scattered, unrelated or absent support mechanisms that do not offer the right incentives for the creation and the development of social enterprises. Another conclusion is that cooperation with partners from different sectors of the society is an important fundament in their work with social entrepreneurship.
\end{abstract}

Keywords: social challenges, sustainable development, social entrepreneurship, social innovation, methodology 


\section{Introduction}

Today, the world is faced with numerous social challenges in terms of economy, society and the environment that it needs to tackle. More than 1 billion people are still living in extreme poverty and income inequality within and among many countries has been rising; at the same time, unsustainable consumption and production patterns have resulted in huge economic and social costs and may endanger life on the planet. Achieving sustainable development will require global actions to deliver on the legitimate aspiration towards further economic and social progress, requiring growth and employment, and at the same time strengthening environmental protection (Desa, 2013, V). When we refer to social challenges, broadly speaking, we are referring to the 'grand challenges' currently faced by the global community. These include challenges ranging from climate change to ageing societies, financialization, poverty, social exclusion, migration and social conflicts. These challenges can manifest themselves on a global scale, or on a smaller scale within local communities. Senge et al. (2008, 6-7) establish that these challenges are interconnected and represent the symptom of a larger unbalanced global system. As soon as we come to understand that, our perspective of the issue will shift and we will be able to see the extraordinary potential for innovations. Social innovations are thus coming (or have come) into the forefront of social development plans, which will be based largely on sustainability principles.

Even though the understanding of innovations has shifted in the course of time, innovation theories are still focusing on the economic effect of innovations and innovation's contribution to economic growth. Nevertheless, in recent times the belief that innovations should be implemented into every aspect of social and economic life - including the private and public sector, as well as social welfare - is gaining traction, partly on account of the increase of innovations in the service sector. Nowadays, it is hard to imagine that a successful company could keep up in the long run with other companies without innovations. A successful company, which is oriented toward sustainable development leverages technological and social innovations, which are largely the result of entrepreneurship.

Social innovations are new ideas, organisations or modes of operation, which are more efficient than previous alternatives in meeting social needs and improving social welfare. Today, millions of people around the world create better ways to address social issues such as climate change, chronic illness, social exclusion and material poverty. Often, their ideas are brought to life with the help of collaborations between the public and private sector, civil society and households. What is more, social innovations can and should come from any sector. The fact is that successful innovations are largely the result of mutual collaborations of more than one sector (SIE, 2012, 6). Murray et al. 
$(2010,168,197)$ state that there are different ways of corporate involvement with regard to social innovations such as corporate social responsibility, hybrid business models that combine business capacities and social objectives, partnerships between social enterprises and corporations. An important reason for the emergence of social innovation is apparently the incapacity of existing structures and policies to solve the most pressing economic and social problems. The authors also point out that many social innovations are conceived in informal life, e.g. over coffee, at lunch or in a bar, within a network of acquaintances. Networks of acquaintances are a rather underestimated source of social innovation. They are successful mostly in the field of environmental protection, health care and nursing care, where they are often ahead of businesses and the state.

According to BEPA $(2011,34)$, social innovation represents new solutions for existing social conditions or issues and influence the process of social interactions. However, not every new way of resolving social issues can be considered a social innovation. Just like technical innovations are considered innovations only after they can be marketed, social innovations must bring to users permanent benefits. There is no uniform definition of social innovations in the European Union, but they are commonly defined as a process of developing ingenious solutions in a social enterprise setting in order to find solutions for social needs and issues, which the market and public sector failed to provide. Social innovations are thus innovations that are not only good for society, but also enhance society's capacity to act. For the OECD $(2010,196)$ social innovation implies conceptual, process or product change, organisational change and changes in financing, and can deal with new relationships with stakeholders and territories. They cover a wider range - from new types of childcare, home health care and internet social networks, to the development of a global fair trade chain and encouraging city dwellers to use bikes instead of cars.

It is not surprising that social entrepreneurship is becoming increasingly important. Social entrepreneurship is a process, a logic of action, which can take place in different organisational contexts: a charity, a commercial organisation, a government organisation, a community organisation, or through a new venture. It is characterized by a set of principles that are typically present: focus on value creation not capture, focus on innovation, not the status quo, focus on sustainable solution not sustainable organisation, and focus on empowerment of participants in the value chain not control of industry forces. The essence of social entrepreneurship is a simultaneous action to create public good by detecting and identifying social problems, as well as using entrepreneurial principles to attain positive social changes. In fact, social entrepreneurship is social innovation, because social enterprises demonstrate how successful the combination of business with social and environmental topics can be. Yunus (2009) believes that there are new and fascinating opportunities for 
implementing social enterprises in the market, and the market is becoming increasingly interesting, attractive and competitive. Rather than focusing on generating profit, social enterprises aim at a good cause, in this way acting as a vector of change. They provide products, services, customers, markets, inflows and outflows; however, their underlying guideline is social usefulness. Yunus provides an alternative option - companies geared toward maximizing profit, but held by poor people.

For a social entrepreneur and social innovation, a group of people from different fields and with different competences, working together toward a particular idea and realizing it by means of support mechanisms is key. Although social entrepreneurs usually start with small, local efforts, they often target problems that have a local expression, but global relevance, such as access to water, promoting small-business creation, or waste management. The innovative solutions that social entrepreneurs validate in their local context often get replicated in other geographies and can spin new global industries (Zahra et al., 2008). The examples of successful social entrepreneurship are impressive. Most famously, the Grameen Bank has shown that social innovation can change even the most conservative of institutions (banking) in a deeply conservative society (Bangladesh) (Yunus (2009).

Osburg and Schmidpeter $(2013,319)$ state that social innovation will be more and more adding the social or responsible dimension to company innovations. Current focus areas for innovations, like e-Health or e-Mobility, offer huge business opportunities for many companies, but a lot of research still has to be done about the social implications of those innovations. For example, the silent cars could be a possible danger for blind people. Then, there is a dilemma whether elderly people really want to stay at home instead of going to the doctor. Today, many questions are unresolved and offer huge opportunities for true social innovation in its pure sense - a new cross-sectorial collaboration to create societal value.

In terms of methodology, the authors of the article reference the findings arising from the research of bibliography, analysis of relevant documents and indepth interviews, as well as a secondary analysis of statistic data. The article initially undertakes to define social innovations and introduce the development process of social innovations and their significance in society. Next, it demonstrates how a society oriented toward sustainability can contribute to a higher quality of life and goes on to introduce social innovations and social entrepreneurship in the EU and Slovenia. The article closes with a future perspective. 


\section{The Future of Global Society Lies in Social Innovations}

Innovation is social when it is socially acceptable and diffused widely throughout society or within certain societal groups; transformed or complemented depending on the circumstances; and ultimately institutionalized as new social practice or made routine (Howaldt and Schwartz, 2010, 21). As with any innovation, "new" does not necessarily equal "good", but in the case of social innovation this at least implies "socially desirable". Occasionally, economic innovation that generates consumer goods can contribute to the development of human welfare just by expanding and diversifying the offering, e.g. by introducing new medications. If such innovations provide users durable benefits, they are deemed social. It follows that social innovations are not exclusive of the non-profit sector. Owing to the increase of corporate social responsibility, they are more and more prominent in successful companies. The development of social innovations can be powered by the government by means of concrete actions through various policies (e.g., new public health care models), markets (e.g., open source software or organically grown food), movements (e.g., fair trade) and academia (e.g., teaching models for childcare), as well as through social enterprises (microcredits and homeless magazines). Social entrepreneurs create institutions to fill gaps in social provision. In the developed world, particularly in Europe, social entrepreneurs face densely populated and highcapability institutional networks for the provision of public goods. Here, social innovations compete with other solutions from the public, private and citizen sector.

Table 1 Innovation Development Cycle

\begin{tabular}{|l|l||}
\hline \multicolumn{1}{|c|}{ Stage of the innovation cycle } & Promotional instrument \\
\hline $\begin{array}{l}\text { Generation of new ideas from the bottom-up } \\
\text { and mobilizing citizens for employment } \\
\text { creation and social inclusion }\end{array}$ & $\begin{array}{l}\text { Small grants to local employment initiatives, } \\
\text { NGOs, or organisations championing } \\
\text { disadvantaged groups in society }\end{array}$ \\
\hline $\begin{array}{l}\text { Development, testing and validation of } \\
\text { innovative approaches and practices }\end{array}$ & $\begin{array}{l}\text { Project support to stakeholders and public } \\
\text { administrations with a view to mobilizing and } \\
\text { empowering them to embrace reforms }\end{array}$ \\
\hline $\begin{array}{l}\text { Accumulation and consolidation of a body of } \\
\text { good practice and success stories to be spread } \\
\text { and transferred }\end{array}$ & $\begin{array}{l}\text { Service contracts to set up suitable repositories of } \\
\text { knowledge/information and the creation of } \\
\text { facilities for its dissemination }\end{array}$ \\
\hline $\begin{array}{l}\text { Enabling social innovations and change by } \\
\text { building bridges and exploiting synergies } \\
\text { between unrelated systems, institutions or } \\
\text { actions of support }\end{array}$ & $\begin{array}{l}\text { Stimulating and facilitating the establishment of } \\
\text { new forms of partnerships between key } \\
\text { stakeholders and governments }\end{array}$ \\
\hline $\begin{array}{l}\text { Testing of hypotheses through experimentation } \\
\text { methods and tools for sound evaluation, and for }\end{array}$ \\
\hline $\begin{array}{l}\text { Increase of awareness; building capacities and } \\
\text { mobilizing for change amongst governmental } \\
\text { administrators and decision-makers }\end{array}$ & $\begin{array}{l}\text { Support of social experiments, in particular the } \\
\text { scaling up what has proven of value }\end{array}$ \\
\hline $\begin{array}{l}\text { Supporting change in structures, organisations } \\
\text { and institutional frameworks }\end{array}$ & $\begin{array}{l}\text { Top-down support to replicate, adapt and scale up } \\
\text { tested innovations which have a clear advantage } \\
\text { over current practice }\end{array}$ \\
\hline
\end{tabular}

Source: BEPA, 2011 
An innovative idea without buyers is not worth much. The whole process from idea to market success of a particular product/service requires great effort in terms of energy and time from the (social) entrepreneur. In their practice of promoting social innovation, the services of the European Commission have developed a typology of promotional instruments necessary for each stage of the development cycle (Table 1).

Murray et al. (2010) propose six steps how to realize a social innovation. The steps are not always sequential and sometimes it is necessary to leave time between two steps to gather feedback on the progress. Despite this, they make up a useful scheme of supportive activities which innovators and innovations need in order to grow and flourish.

Prompts, inspirations and diagnoses: At this stage, we outline all areas that require innovation/improvement. We identify the problem, and rather than just identifying its symptoms, we find the real source of it. Asking the right questions is the first step in the direction toward finding right answers.

Proposals and ideas: Next, we generate ideas. There are several methods to develop creativity and new ideas. It is crucial for the ultimate success of social innovation to include a wide circle of actors as early as in the inception process.

Prototyping and pilots: It is essential that ideas be refined through trial and error. The key at this stage is to act swiftly, operate at low costs and obtain feedback from potential buyers/users and experts.

Sustaining: Only a small portion of ideas will survive this entire process and ultimately flourish. When we start to address a certain problem in a new way with a new idea, we often come across various alternative ways to solve the same problem. Therefore, improvements continue to be important. The main factor is naturally the response of the target audience, but we also cannot disregard different evaluation methods. In the public sector, maintaining an innovation means integrating it into the budget. Beyond the public sector, it means that the idea must be viable in the market - so that the company can cover its expenses with the service/product.

Scaling and diffusion: This stage, there are different possible strategies as to how to disseminate the innovation e.g. via licensing or franchising. Alternatively, if the idea is inspiring or someone else simply copied it, it can be disseminated unorganized. Perhaps the potential of social innovation will be recognized by decision-makers and the new idea will become a successful model for solving particular problems - normally, this is associated with more available public finances. Above all, dissemination relies on an exchange of ideas and knowledge with other organisations.

Systemic change: This is the ultimate goal of social innovation. A change in the system is usually an interaction of social movements, business models, legislation and regulations, data and infrastructure and, of course, a completely 
new mindset and course of action. Here, we often confront with the previous regulation of the respective field. In order for the innovation to succeed, it needs to be economically viable, supported by new technologies, supply chains, institutions, knowledge and regulatory fiscal support. Social innovation often denotes transformations in the public and private sector, and it usually takes time for one to gain ground.

According to Senge et al. $(2008,45)$ managers have to consider three things in the process of social innovation:

- See the bigger systems in which companies operate;

- Cooperate with the internal and external environment of the organisation; or to collaborate across boundaries; and

- Focus on what really matters to create the future they truly want.

By definition sustainable development as a new paradigm represents a form of social innovation that has the potential to influence almost every aspect of human existence and cut across all sectors of our societies. Sustainable development innovation must, in contrast to economic innovations, incorporate the added constraints of social and environmental pressures and consider future generations (Hall and Vrendenburg, 2003). Mulgan (2010) describes that two sources exist to derive a social change, either by heroic and energetic individuals (e.g. Nobel-peace winner Muhammad Yunus) or movements of millions of people (e.g. environmentalism). It still seems that one more source needs to be added: The business or commercial opportunity within a social innovation that might also serve as an origin to develop positive social change.

Recently, social innovations came into prominence because they are an alternative to the existing methods on how to overcome the crisis, offering longterm solutions to current issues and new development opportunities.

\section{Social Entrepreneurship and Value Creation}

Many social entrepreneurs operate in developing countries that have no structures or resources that would enable and support traditional entrepreneurship. Therefore, social entrepreneurs must create novel business models and organisational structures, and unique strategies for brokering between very limited, disparate and often dynamic resources to create social value.

Even though value can be assessed in monetary and non-monetary terms, value has been generally conceptualized as a cost-benefit trade-off. Different assessments and perceptions of value between firms, customers, and cultures increase the complications. The process of value creation also varies strongly depending on the specific source that leads the process and the level of competition and isolating mechanisms about the created value (Lepak et al., 
2007). In social entrepreneurship, value creation is generated from following the organisation's mission as social entrepreneurs - who are individuals, groups, networks, organisations, or private-public partnerships-look for novel ways to solve societal issues through pattern breaking. Social innovation as a "novel solution to a social problem that is more effective, efficient, sustainable, or just than existing solutions and for which the value created accrues primarily to society as a whole rather than private individuals" (Phills et al., 2008, 36). This definition implies that by creating value for society, social innovation would contribute value to communities and therefore improve productivity by creating new and sustainable capabilities, assets or opportunities for change.

To approach the question of how value is created, Ney et al. $(2014,60)$ mention that, first, value creation refers to the design and delivery of products and services. Some social entrepreneurs will introduce entirely new practices to the provision of public goods and social services. Second, value creation also involves the financing practices, human resource management and marketing regimes to deliver products. Some social entrepreneurs may provide a rather common product or service, say health care, but are radically innovative in their financing, managing and marketing practices. In this way, the framework captures social innovations that create value in terms of the services or products, in terms of management and in terms of both.

Social innovations aim to create value for society (e.g., Mulgan et al. 2010; Phills et al. 2008). In the BEPA study $(2011,102-105)$ the authors underline that the measurement of innovation has recently progressed thanks to the attention of policy-makers to develop new innovation metrics (e.g. EU innovation scoreboard), but the lack of agreed tools to measure the social value and social returns produced by social innovations is a major obstacle. They link it to the wider ongoing debate about the values of environmentally or socially related activities not accounted for in the gross domestic product.

\section{Methodology}

There is no generally accepted methodology for measurement of social innovation now. Problems with establishing uniform measures and procedures start with the lack of a generally accepted definition of social innovation, a method for establishing variables, and the issue of measuring social innovation's performance or effect. Due to the restrictions imposed by national or international standards, e.g. IFRS and US-GAAP, the financial accounting can only be made up from transactions that have direct influence on the organisation within the boundaries of its system. Another issue about measuring social innovation is the lack of objectivity (e.g., what is good for society) and the inability to standardize procedures, etc. (see for instance Mulgan, 2010; Osburg and Schmidpeter, 2013). 
The article is based on primary and secondary data sources. Secondary sources are represented by technical articles from academic databases and electronic documents (e.g., analyses, reports, estimates, proposals, etc.) of national and European institutions and literature. Primary data were obtained by means of performing in-depth interviews with a focus group of players from the state, private and civil (non-profit) sector and social entrepreneurs in Slovenia.

It builds on the assumption that social innovations provide one way to achieve sustainable development of the society. Social innovations complement economic innovations, and their focus lies primarily on assuring social welfare. We believe that their development is of key importance for overcoming the economic crisis in the Slovenian setting.

Testing of the thesis was narrowed down to the Slovenian perspective; we were interested in how social innovations are developing in Slovenia, the current state of affairs in Slovenia in this field and whether it is justified to expect a systemic development of social innovation by the state. In a time when social and economic issues are getting more and more severe and when old problem-solving methods fail to work, social innovations seem as a new suitable option or alternative. Starting points of our research are sustainably oriented society and social entrepreneurship from the EU's viewpoint.

\subsection{European Union and Sustainable Development}

A sustainably oriented society must ensure a healthy environment, clean water, air, and safe food. It should support a healthy human development without jeopardizing future generations. This means that a sustainably oriented society demands a long-term business activity, which strives for optimum profit by reducing the exploitation of natural resources to the minimum, relying instead on their sustainable use. Its development is focused on the process of transformations over a longer period, in which the use of natural resources, directing of investments, technological development and institutional progress are adapted to the needs of the present and future generations.

In addition to social benefits, social enterprises pursue sustainability in the field of environment and economy. This means that social enterprises generate at least one portion of its revenues in the market so they are not completely dependent on national funds and subsidies.

We also should not forget that profit-oriented companies or entrepreneurs too could contribute to the implementation of broader social objectives, if they incorporate the corporate social responsibility standard in their quality standards. This means that they accept as their mission a commitment to donate part of the generated profit for the realization of wider community needs, to the community in which it operates. Entrepreneurs are increasingly aware that they 
can attract clients and enhance their image through socially and environmentally friendly operations. This has led to a series of collaborations between businesses and third or public sector organisations; developments in the field of corporate social responsibility; increased private sector provision of public services in some countries and; the development of new social business models (The Young Foundation, 2010, p. 42).

The European Union is faced with great budget restrictions, demographic changes and globalization. Competitiveness, the ability to create jobs and a decent living standard of EU citizens are relying more and more on the capacity to encourage innovation in terms of products, services, business and social processes and models. Innovations, whether classic such as technological, service and organisational, or new social innovations are at the heart of the new Europe 2020 strategy, as they are supposed to represent the best way to successfully overcome economic and social issues. Europe 2020 gives priority to knowledge and innovations (smart growth) and promotes a more competitive and green economy (sustainable growth), enhancing the economy through a high employment rate which strengthens social and territorial cohesion (inclusive growth).

The framework of Europe 2020, the flagship initiative Innovation Union, the European platform against poverty and social exclusion and the Single Market Act are documents, which relate to social innovations, too. The Commission places its focus on social economy and social innovation, both in terms of territorial cohesion and in terms of finding original solutions for social issues, especially regarding the fight against poverty and social exclusion, in order to promote a "highly competitive social economy" (European Commission, 2011).

In the framework of innovations, social innovations provide an opportunity to create new solutions, to connect with citizens and promote better quality of life. In the words of Barroso $(2011,3)$ : "Social innovation should be at the core of our social market economy and also contribute to make our social market economy more competitive. If we are prepared to adapt to our fast-changing world, if we address today's social and economic challenges in a smart way, it has the potential to unleash fresh waves of creativity and innovation and create new sources of sustainable growth and jobs."

The Commission supports the following most common methods in the field of social innovations (BEPA, 2011, $81-96$ ):

- knowledge-sharing and dissemination;

- participative processes for stakeholders in the preparation and implementation of policies; 
- policy coordination and capacity building; supporting studies, research and evidence for good practice for policy planning and policy development and for advancing knowledge on social innovation;

- support of social experiments;

- support of social entrepreneurs and enterprises; infrastructure and enabling factors to support and nurture social innovation.

There are numerous organisations/networks/companies that are involved with social innovations in the EU. Among them are for instance: NESTA - UK's Innovation Foundation (http://www.nesta.org.uk), The Young Foundation in England (http://www.youngfoundation.org), ZSI - Centre for Social Innovation in Austria (https://www.zsi.at), globalna skupnost SIX - Social Innovation Exchange, which includes individuals and organisations both from civil society and global companies, public agencies and academia, all of whom are dedicated to promoting social innovation and spreading the interest in this respective field (http://www.socialinnovationexchange.org/). The European Commission is the main financier of the Euclid network, which connects actors from the civil sector (NGOs, non-profit and voluntary organisations) and acts as an important advocate and promoter of social innovation (http://www.euclidnetwork.eu/).

Social economy is currently one of the fastest growing sectors of business activity in the EU, employing, according to some data, more than 11 million people, which is $6 \%$ of the total of persons employed. As social enterprises are not homogeneously defined and could take different legal forms, most countries do not collect information on the number of social enterprises; instead, they collect data on the number of organisations with particular legal forms - i.e. the number of social cooperatives, associations, social purpose companies, and so on. Approximately one of four newly founded businesses is supposed to be a social business. The largest share can be found in Belgium, Finland and France (European Commission, 2011).

Figure 1 Social Economy Organisations by Country (Top 10)

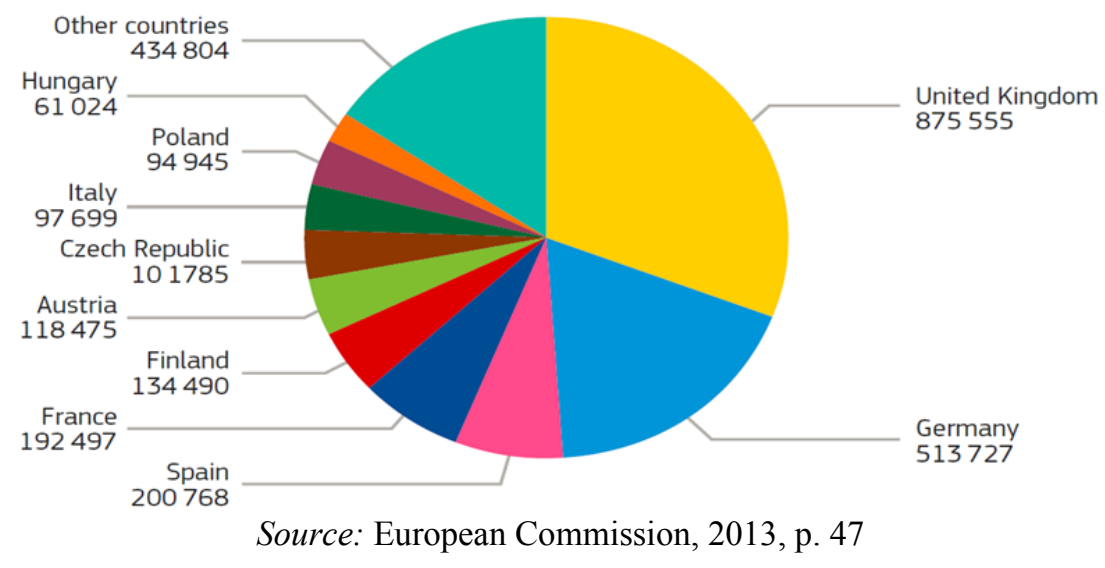


Social economy enterprises in the EU make up 3 million organisations or 10 $\%$ of all European companies, employing $6 \%$ of the total working population. With a staggering $70 \%$, the largest share is employed by nonprofit organisations, followed by cooperatives with $26 \%$ and mutual societies with 3 $\%$. Social economy enterprises are present in almost every economic sector, such as banking, insurance, agriculture, crafts, various commercial services, health care and social services etc. (European Commission, 2014). According to a research conducted by Črnak-Meglič and Rakar (2009), the social economy sector or the third sector in Slovenia employs a meager $0.74 \%$ of the workforce. This means that this sector in Slovenia has the potential to provide jobs for almost 48,000 people.

\subsection{Social Innovations and Social Entrepreneurship in Slovenia}

As a developed country and an EU member, promoting innovations is in the forefront of Slovenia's economic and social recovery strategy (e.g., National Reform Programme 2014-2015, Resolution on the National Research and Development Programme 2011-2020). Understanding innovations in these documents is from a traditional economic point of view - emphasizing products, processes, the organisation and marketing. The role of social innovation is less prominent, as it is only found in indirect connections and methods with which social innovation can contribute to implement national objectives. The reason for this may be that in Slovenia the structure of the social security system and public services did not really change that much from the socialist period. The economic crisis puts pressure on the state with regard to public finances, which has additionally hampered the payment of social benefits and other expenses (public sector wages, pensions, employment subsidies, etc).

Figure 2 Spheres of Social Innovation

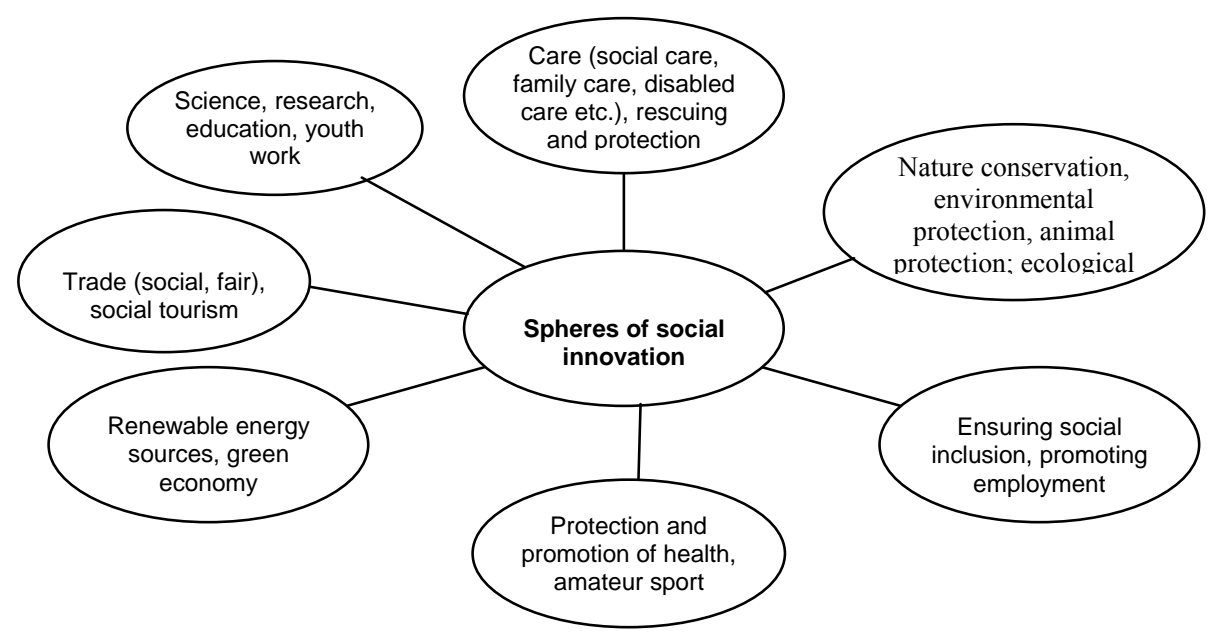


A step forward in the development of social innovations in Slovenia is the Social Entrepreneurship Act (OJ of RS, No. 20/2011) which entered into force in early 2012. This document is the most direct instrument to promote the development of social innovation by promoting the development of social enterprises. The fields and activities of social enterprises include all vital elements for ensuring social and economic welfare where social innovation can play a crucial role (see Figure 2).

Social innovations are also less prominent due to their relative recentness and distinct features. An important feature of social innovations is their double process dimension, acting from the bottom up and from the top down. In addition to cooperation and carrying out activities at the international community level, there is also a need for regional, national and local incentives. The most social innovations come about at grass-root level.

Interviewees believe that the supportive environment for social innovations and social entrepreneurship in Slovenia is poorly developed. If we want an advanced society, we need continuous innovations in politics, public administrations, NGOs - at all social events, really.

In addition to some public funds and foundations, which are not specifically aimed at social innovations, the Social Entrepreneurship Act opened the door to the first social incubators (promoters and intermediaries between the demand and supply of social innovations) and other similar support services for social innovations, even though still lacking any real financial support and investments. There are several companies, organisations and individuals in Slovenia, which act socially innovative without defining their operations as such. However, it is evident from the records of social enterprises that there were 63 social enterprises registered in Slovenia as at 18 December 2014 (Figure 3).

Figure 3 Records of Social Enterprises

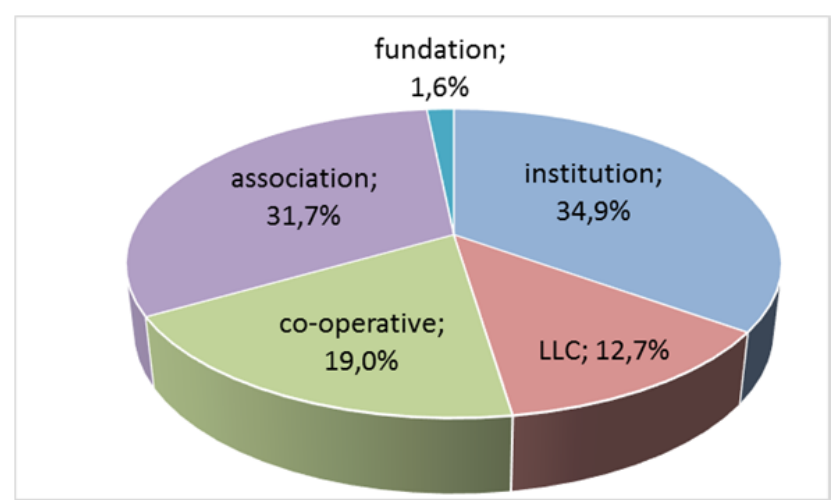

Source: Ministry of labour, family, social affairs and equal opportunities, 2014. 
According to European standards, around 18,000 operational societies, 250 foundations, 250 private institutes that are defined as non-profit companies, 150 companies for the disabled and some ten co-operatives could be classified as such in the social economy sector (Radej, 2011). Since in Slovenia the state plays the main role in providing public goods and services, this might be the reason for the underutilized potential of social innovation in the country.

Interviewees agree that the concept of social innovation and social entrepreneurship in Slovenia has not yet been generally accepted, in large part due to the word "social". Alluding to the past socialist system, it creates terminological confusion and leads to the inadequate understanding by many decision-makers about the added value of social innovations - which is an active and dynamic contribution to comprehensive economic development seeing "social" only as passive rescuing of vulnerable groups. An important pillar for the development and implementation of social innovations is the development of the civil sector. Social innovations provide great opportunities for addressing the needs of residents (e.g., recycling and home assistance), even though there are many factors hampering their development through the actions of civil society (and social enterprises). These factors are mostly a legacy from the past and include the following (OECD/MDDSZ, 2010, 12):

- Conceptual confusion;

- Stigmatization of entrepreneurship and a lack of positive vision of entrepreneurs and entrepreneurship;

- The lack of entrepreneurial capabilities of social economy organisations;

- No clear role for the social economy in the Slovenian social system;

- Strong stigmatization of certain target groups;

- The distance between the social economy, the state, and their low level of communication. The state does not consider social economy organisations as serious partners in meeting the needs of people or does not consider important their contribution to general social welfare; and

- A lack of intermediary public bodies between municipalities and the state incomplete decentralization, which is particularly important for meeting regional needs in light of Slovenian regional diversity.

According to interviewees, social innovations are important for Slovenia and beyond, for the whole world, even as pointed out by Stritar (2014), adding that social innovations are mostly important for those people who are marginalized by technological innovation. In particular, interviewees highlight youth employment, the pension and health care system and self-sufficiency as those areas, where Slovenia needs social innovations the most. Puh (2014) when thinking in terms of social economy provided an interesting perspective. Social economy plays an important role in association with the local and national structure. It connects profit-making with solidarity (ethical economy); generates 
high-quality jobs adjusted to individuals (ergonomics); supports sustainable development - environmental and technological innovations (ecology); strengthens social, economic and local/regional bonding, generates social capital, promotes active citizenship and most of all, puts the human into the forefront of all this. All three principles are the pillars of the eTRI business model, which enables sustainable implementation of social entrepreneurship in Slovenia in the form of eTRI franchises. Their mission is to create green jobs for vulnerable groups. This is a concrete example of social innovation, which offers a new innovative solution and an alternative to existing business models.

Social innovations are not only important for society and the environment, but also for saving the economy, is the consensus of the interviewees. Addressing social and environmental problems, in fact, means saving the economy, as all three elements are interconnected. Mitrovič (2014) highlights the strategic importance of social responsibility and at the same time innovative embedding of social responsibility in the corporate context of a company trying to find its competitive edge in this process. Nearly all activities in this value chain of the company touch on various communities in which the company operates, generating either positive or negative effects. Many times employees of a company and clients are much more aware of sustainable actions and impacts on the social environment. In other words, a company, which is aware of the significance of social innovations, can find a great source of inspiration in its employees and users, who are keen to participate. According to Špec Potočar (2014), values are mainly left to us in that we maintain and improve the quality of life. Against this background, rural environment and local self-sufficiency are crucial. Possibilities for entrepreneurship, for inclusion of partnerships and the development of social innovations are numerous in these spheres; we just need to pursue them actively, instead of waiting for state incentives or others for funding. Bačar (2014) points out Google and Facebook as two examples of classic (economic) social innovations, which revolutionized communication in society. He believes that social innovations create a better world by efficiently solving existing cultural, social, environmental and economic challenges. Individuals, groups or organisations develop them, and they may take place in the nonprofit, profit or public sector. In fact, practice shows that social innovations successfully connect all three sectors. Slapnik (2014) points out cooperatives and corporate social responsibility as an important link between social innovation and the economy. An example from the UK is provided where volunteerism and social responsibility are highly cherished, unlike in Slovenia. Perhaps a greater emphasis on social innovations in Slovenia in the future could turn this situation around. The interviews also reveal that social innovators in Slovenia collaborate, encourage and help each other, but mostly operate on an individual basis. Cooperatives in Italy, Spain and the UK are given as examples in terms of collaboration. 
Among the problems of social innovations, interviewees highlight the lack of funds, failure to grasp the significance of social innovation, unwillingness to take risks and lack of intersectorial connection. Their views on the role of sectors in encouraging and implementing social innovation, however, differ. Most believe that civil society is the initiator and executor, as it is in direct contact with the field and is therefore capable of quickly identifying opportunities or issues as they arise. The education sector could play a more decisive part, mostly with regard to illuminating this topic, raising awareness and encourage youngsters; if it was more flexible and socially responsible, it could also implement social innovation. Teaching about the significance of the social and environmental dimension starts as early as in kindergarten where children are taught to save water and separate waste. The state can promote innovation by eliminating bureaucratic obstacles, in addition to including the economy - also through state measures. Successful companies have figured out that without social innovations there is no chance for long-term growth and development.

In order to specifically investigate social entrepreneurship, the existing GEM survey (Global Entrepreneurship Monitor) needed to be complemented with specific screening questions that could identify social entrepreneurs in the population. The GEM is a multi-country initiative with the explicit objective of facilitating cross-country comparison of entrepreneurial activity by using the exact same measurement approach in all countries involved in the study. Initiated in 1997, GEM has expanded to over 80 participating countries in the past decade. Each year GEM surveys representative population samples of at least 2,000 randomly selected adults in each participating country. The surveys are conducted by telephone or face-to-face between May and August in the national language(s) and facilitated by a translation and back-translation of questions. From each individual interviewed in the GEM sample, records are collected of gender, employment status, educational background, and household income. Once collected, the data are weighted to reflect the national population and harmonized with the other countries by the GEM coordination team. A study conducted by GEM (Rebernik et al., 2010, 112) showed that society in Slovenia expects companies to give part of their profit back to the community by supporting important social and environmental projects. Additionally, companies should invest more into corporate social responsibility activities if they want to restore the trust of the public, which they had lost because of the global crisis. It is also interesting to note that entrepreneurs than the government - something that all interviewees agree with, in general, can address social and environmental issues and community issues more efficiently.

\section{Conclusion}

Sustainable development has become a global metaphor that guides many international efforts, and supports specific framing of the complex set of 
problems and opportunities underlying economic and social growth and development. The phenomenon of social entrepreneurship challenges our assumptions about human behavior and economic action. It also challenges our beliefs about the role of entrepreneurship in society. Social entrepreneurship is a complementary economic approach that is based on value creation and operates by its own rules and logic. Social innovations are important for addressing social, environmental and economic problems, because they greatly shape sustainable development. In Slovenia, social innovations are important in various fields, especially employment, social inclusion, demographic changes, health care, education, finance, political structures and social integration. In general, interviewees showed greater awareness and support for social innovations, so one might say that social innovations in Slovenia are to an extent fairly well developed. The greatest difficulty with the implementation of social innovation into the social setting is the weak supportive environment, lack of funds and the unwillingness of the state and other important actors to take risks and make changes.

Compared to other European countries, the civil sector in Slovenia is poorly developed and/or supported by the state and companies. There are also only a handful of examples of market-oriented civil society organisations. The Social Entrepreneurship Act is expected to boost the growth of this sector. The private sector is witnessing the trend of social innovation or, at least, social responsibility. At the state level, the trend of social innovation is existent, but not specifically aimed at this field. The obstacle in the development of social entrepreneurship is scattered, unrelated or absent support mechanisms that do not offer the right incentives for the creation and the development of social enterprises. The existing entrepreneurial supportive environment requires a thorough overhaul and upgrade by developing social entrepreneurship incubators and co-working spaces. The key is to create an understanding, supportive environment, which is aware of the significance of social effects/impact brought on by social innovations. With this goal in mind, the Ministry of Labour, family, social affairs and equal opportunities commissioned a study on measuring its social effects. Setting up rules on how to measure social effects might help companies to prove such effects and help users to make purchases of products and services offered by e.g. social enterprises.

Considering the answers we had obtained and the reflections on the significance of social innovations for the economy, all surveyed individuals displayed great consensus with regard to the fact that social innovations are necessary for the sustainable development of society and key for Slovenia's journey toward overcoming the economic crisis.

While reviewing EU's perspectives in the field of social innovation, the authors have established that there are two fundamental reasons why the EU supports social innovation. First of all, constituting a new approach to address 
current issues, social innovations can help remedy the situation in the EU and steer it back to the path of successful economic development. Second, should this strategy succeed, it could provide a new groundwork in the global economy so that the EU can once again become competitive and successful on the international scene. This is why it has adopted a new strategy, prompting member countries to attempt to remedy the situation in their respective areas in line with their circumstances and resources. However, the EU has also assumed a part of the responsibility upon itself by promoting and funding individual countries or local activities, projects, programmes, etc. EU's innovation policies support the authors' thesis that social innovations and value creation importantly drive forward the sustainable development of society and that their development is also crucial for Slovenia's way out of the crisis. The thesis, however, can be confirmed only in part. There is no uniform methodology in place for the purpose of studying the influence and success of social innovations and value creation, which could demonstrate their actual success through numbers and indicators.

To sum up social entrepreneurship could be an important means to flexibly adapt to and take care of the changing scales and types of social needs underlying sustainable development dynamic that challenges our ability to grow in a way that is compatible with both our current needs and the emerging needs of future generations.

\section{References}

Bačar, F. (2014). Interview with the author. Novo mesto, 24. April.

BEPA (2011). Empowering people, driving change: Social Innovation in the European Union, http://ec.europa.eu/bepa/pdf/publications_pdf/social_innovation.pdf.

Černak-Meglič, A., Rakar, T. (2009). The role of the third sector in the Slovenian walfare system. Teorija in praksa, 46(3): 237-254.

Desa (2013). World Economic and Social Survey 2013: Sustainable Development Challenges. New York: United Nations.

European Commission (2011). Social Business Initiative - Creating a favourable climate for social enterprises, key stakeholders in the social economy and innovation (SEC(2011) 1278 final).

European Commission (2013). Social economy and social entrepreneurship - Social Europe guide, Volume 4, Luxembourg, Publications Office of the European Union.

European Commission (2014). Social Economy, http://ec.europa.eu/ enterprise/ policies/sme/promoting-entrepreneurship/social-economy/\#h2-).

Hall, J. and Vrendenburg, H. (2003). The Challenges of Innovating for Sustainable Development. MIT Sloan Management Review, (3): 61-68.

Howaldt, J, Schwarz, M. (2010). Social innovation: Concepts, research fields and international trends, http://www.asprea.org/imagenes/IMO\%20Trendstudie_ Howaldt_englisch_Final\%20ds.pdf. 
Lepak, D. P., Smith, K. G., Taylor, M. S. (2007). Value Creation and Value Capture: A Multilevel Perspective. Academy of Management Review: 32 (1), 180-194.

Mitrovič, Z. (2014). Interview with the author. Novo mesto, 6. June.

Mulgan, G. (2010). Measuring Social Value, http://www.ssireview.org/articles /entry/ measuring_social_value.

Murray, R., Caulier-Grice, J., Mulgan, G. (2010). The Open Book on Social Innovation, http://www.nesta.org.uk/publications/open-book-social-innovation.

Ney, S. et al. (2014). Social entrepreneurs and social change: tracing impacts of social entrepreneurship through ideas, structures and practices. Int. J. Entrepreneurial Venturing, 6 (1): $51-68$.

OECD (2010). Social Entrepreneurship and Social Innovation. In SMEs, Entrepreneurship and Innovation, http://ec.europa.eu/internal_market/social_business /docs/ conference/oecd_en.pdf.

OECD/MDDSZ (2010). Izboljšanje socialne vključenosti na lokalni ravni preko socialne ekonomije: Poročilo za Slovenijo, http://www.mddsz.gov.si/fileadmin/mddsz. gov.si/pageuploads/dokumenti_pdf/seminar_soc_podjet_oecd_porocilo.pdf.

Osburg, T., Schmidpeter, R. (2013). Social Innovation: Solutions for a Sustainable Future, http://www.thomasosburg.com/_Osburg_Social_Innovation.pdf.

Phills, J. A. J., Deiglmeier, K., Miller, D. T. (2008). Rediscovering Social Innovation. Stanford Social Innovation Review, 6 (4), 34 - 43.

Puh, L. (2014). Interview with the author. Novo mesto, 24. April.

Radej, B. et al. (2011). Presečno določanje razvojnih prioritet. Ljubljana: Slovensko društvo evalvatorjev.

Rebernik, M. et al. (2010). Slovensko podjetništvo v letu krize. GEM Slovenija 2009. Maribor: Ekonomsko-poslovna fakulteta.

Senge, P. et al. (2008). The Necessary Revolution. How individuals and Organisations Are Working Together to Create a Sustainable World. New York: Doubleday.

SIE (2012). Social Innovation Europe. Financing Social Impact; funding social innovation in Europe - mapping the way forward, European Commission, http://ec. europa.eu/enterprise/policies/innovation/files/funding-social-innovation_en.pdf.

Slapnik, T. (2014). Interview with the author. Novo mesto, 24. April.

Stritar, T. (2014). Interview with the author. Novo mesto, 24. April.

Špec Potočar, M. (2014). Interview with the author. Novo mesto, 24. April.

Zahra, S. A., Rawhouser, H. N., Bhawe, N., Neubaum, D. O., \& Hayton, J. C. (2008). Globalization of Social Entrepreneurship Opportunities. Strategic Entrepreneurship Journal, 2(2): 117-131. 